it approaches the border of the pupil, and especially as it passes on to the iris, it is seen to be accompanied by a small, pale, but well-defined image, which always lies between the first image and the centre of the pupil, the distance between them decreas. ing as they move towards the centre, where they finally coincide. By means of the ophthalmophakometer-an instrument consisting of three incandescent lamps and a telescope arranged on an arc of $86 \mathrm{~cm}$. radius - it was found possible to measure the radii of clirvalure of all the reflectin $r$ surfaces. The foci of the two reflecting surfaces of the cornea were found to coincide, a fact which accounts for the coincidence of the two corresponding images at the centre of the pupil, and for Helmholtz's failure of finding the fainter one.

It is evident that since the light reflected from the successive surfaces does not fall upon the retina, it is lost for visual purposes. But a comparison of the percentages of loss in the case of the eye, and in that of a simple lens tells greatly in favour of the former as an optical instrument. In the eye the percentage of useful light is 97 , in a simple lens 92 , and in a compound optical instrument correspondingly less. But the light reflected by any of the internal surfaces is also liable to be reflected back into the eye or the optical instrument, with the effect of superimposing a more or less faint patch of light upon the image on the retina. This is termed the noxious light (lumière nuisibie) by $M$. Tcherning. In a simple lens this amounts to $\frac{1}{6}$ per cent., whilst in the eye it is as low as 0.002 per cent. But faint as it is, it is capable of giving rise to two light impressions due to double refiection, one at least of which has been actually observed in the human eye. "The easiest way of observing it," says M. Tcherning, "is to look straight forwards in a dark room, holding a lighted candle in the hand about $20 \mathrm{~cm}$. from the line of vision. On moving the candle gently from side to side a pale image of the flame is seen on the opposite side of the line of vision, distinct enough to show that it is inverted; it moves symmetrically to the candle with respect to the line of vision. The rays which form this image have undergone, besides several refractions, two reflections, one at the posterior surface of the crystalline and another at the front surface of the cornea." Another image was expected to be formed by a similar refiection at the anterior surface of the crystalline. It was found in an artificial eye, but not in the human sense-organ. However, an easy calculation of the optical system of the eye explains this circumstance. The focus of the reflected rays is very near the crystalline lens itself, so that they must be much dispersed by the time they reach the retina. To enable the image to be formed on the retina, the object would have to lie between the cornea and the crystalline, but on attempting to form a luminous point at that place by optical means it is found that the "useful rays" fill the eye to such an extent as to render everything else invisible.

It is found that different eyes differ in their capacity of seeing the first of the two additional subjective images. Short-sighted people find it very indistinct unless the candle is held close to the eye, or convex glasses are used. As the maker of optical instruments utilises the accessory images for testing the degree of polish and the accurate centreing of the lenses, so the physician is enabled to make valuable inferences from them as to the structure and condition of the eye he is examining, and the additional images discovered by M. Tcherning appear to be of considerable physiological importance. E. E. F. d'A.

\section{A BOTANIST'S VACATION IN THE HAWAIIAN ISLANDS.}

SOME weeks ago we reprinted from the Botanical Gazette

(Indiana) a part of the first instalment of Prof. D. H. Campbell's interesting account of his vacation in the IIawaiian Islands. The following is the chief portion of the second and concluding instalment, published in the January number :-

Beside visiting the isle of Oahu, I made short trips to the islands of Hawaii and Kauai. The former, the largest of the group, and the only one where volcanic action is still going on, is reached by steamer in about thirty-six hours from Honolulu. On the way, the islands of Molokai, Lanai, and Maui are passed. The first, a barren-looking and forbidding spot, is the location of the leper settlement, to which all persons afflicted with leprosy are sent as soon as their condition becomes known.

NO. I 2 I 5 , vOL. 47]
Maui, the largest of the islands next to Hawaii, consists of two portions connected by a narrow isthmus. The whole eastern half is nuthing more nor less than the body of an immense extinct volcano, ten thousand feet high, and with a crater nearly ten miles across. The other end of the island is an older formation. This island is said to be very interesting botanically; but, unfortunately, my time did not permit me to visit it.

Very soon after sighting Maui, the three great mountain masses of Hawaii began to loom up. The day was clear, and the whole formation of the island became visible. It consists of three great volcanic cones, of which only one is now active. The highest summit, Mauna Kea, is nearly 14,000 feet above the level of the sea; the next, Mauna Loa, lacks but a few hundred feet of this; yet so great is the breadth of these masses that one fails to realise their immense height. Our first landing was at Mahukona, on the leeward side of the island, a most forlorn expanse of bare lava with scarcely a trace of vegetation, except a few unhappy-looking algaroba trees planted about the straggling buildings that constituted the hamlet.

We lay all day at this inhospitable station, not getting away until evening. A beautiful sunset and a fine glimpse of the peak of Mauna Kea glowing with the last rays of the sun, form my most pleasant recollections of this desolate place.

What a change the next morning! On awakening we found ourselves entering the harbour of Hilo. Here everything is as green as can be imagined, and luxuriant vegetation comes down to the very ocean's edge. The town is built on a bay fringed with cocoa-nut trees and embowered in a wealth of tropical vegetation. Owing to the great annual rainfall (about I80 inches), as well as to the fact that Hawaii is the most southerly of the islands, the vegetation here is the most luxuriant and tropical found in the whole group. I remained in Hilo for six days and collected some most interesting specimens. Through the kindness of Mr. Hitchcock of Hilo, I was enabled to spend the night at his camp in the woods near the town, and the greater part of two days collecting in the vicinity. The forest here is most interesting. Mr. Hitcheock was starting a coffee plantation and has cut trails through the woods in several directions, so that collecting was very convenient. There is great danger of glosing one's self in these woods where there are no trails, as much of the forest is an almost impassable jungle. In these moist forests ferns and mosses luxuriate, and every trunk and $\log$ is closely draped with those beautiful growths. Flowers are almost entirely wanting, a fact repeatedly observed by collectors in tropical forests. I saw here fully developed specimens of tree-ferns. The finest of these were species of Cibotium. Many had trunks from fifteen to twenty feet high, and some must have been fully thirty. The most beautiful were some with trunks ten to fifteen feet high, as these were more symmetrical and had fincr fronds than the taller ones. I measured the leaves of one that had fallen over, and roughly estimated the length as eighteen feet. I have no doubt that specimens fully twenty feet long could be found. These giant fronds, arching high over one's head as one rides on horseback under them, present a sight at once unique and beautiful. Growing upon the trunks of these ferns were many epiphytic species, the most peculiar of which was Ophioglossum pendulum, with long strap-shajed leaves, a foot or two long, and a spike of sporangia sometimes six inches long. Exquisite species of Hymenophyllum and Trichomanes, the most ethereal of all the fern tribes, with almost transparent, filmy leaves, were common, sometimes completely enveloping the trunks of the trees. Of the terrestrial ferns, which abounded everywhere, two were especially notable as; representing groups unknown in the United States. One of these, Gleichenia dichotoma, forms extensive thickets on the borders of the forest, and in the Hilo district extends down almost to the sea-level. The other, Marattia Douglasii, a very large fern with leaves eight to ten feet long in well-grown specimens, has fleshy dark green leaves, and thick stipules sheathing the base of the leaf-stalks. Several species of Lycopodium and Selaginella were common, and a good variety of mosses and liverworts. In these forests wild bananas are common, and most magnificent plants they are. Sheltered from the wind, the superb great leaves develop to their full size, without being torn in the least, and the whole plant is a study of beautiful form and colour.

Coffee is being extensively planted in this region as well as upon the lee side of the island, and as the quality of the berry 
is exceptionally fine, this promises soon to be a leading industry in the islands.

About Hilo especially, but common also elsewhere, was a very conspicuous black fungus, that covered the leaves completely in many cases, and attacked indiscriminately a great variety of trees.

From Hilo I proceeded to the volcano of Kilauea, some thirty miles distant, and about 4000 feet above the level of the sea. As this volcano has so often been the theme of travellers' descriptions I will not linger over it. In the vicinity are many interesting plants, among them a species of Vaccinium with sub-acid yellow and red berries something like cranberries. These "ohelo" berries are much esteemed, and are especially good when cooked. Some two miles from the volcano is a superb grove of koa trees, the largest trees I saw anywhere in the islands. One of these standing alone, and with magnificent spread of branches, must have been ten feet in diameter. The road to the volcano lies for much of the way through a fine forest. In the lower part the ohia trees were loaded with their beautiful crimson fruit, and present a very showy appearance. Of flowers, the species of Ipomæa were the most conspicuous ; but the scarlet flower-bracts of Freycinetia were conspicuous at times, for here this latter plant may often be seen running to the tops of the tallest trees.

The glory of this road, however, is the tree-ferns, which all along excite one's admiration. The carriage road is not yet completed, and about thirteen miles must be done on horseback. Of this more than a mile is over a corduroy road made out of the trunks of ferns! Such a road, if not very durable, is yet very pleasant to horses. As these trunks lay prostrate, in the damp atmosphere, most of them were already sending out new fronds, and in due course of time the road will be fringed with a hedge of great fern-leaves. Indeed, in some of the more open parts of the road farther down, where the ground is completely occupied by a small treefern growing in dense thickets, as these are grubbed out to make way for cultivation, their trunks are piled up to form fences, and soon sprout uut so that they make a beautiful and close hedge of fern-leaves.

On leaving the volcano I went down on the other side of the island. The rain being almost entirely intercepted by the mountains, this leeward side is very dry, and the ride to Punaluu, where we were to take the steamer, was not especially pleasant. Vegetation is very scanty, and nothing particularly interesting was noted in this line. The soil on this side of the island, especially in the district of Kona, is very fertile, and when water can be had, produces magnificent crops of all the tropical staples, pine apples, cocoa nuts, coffee, sugar, \&c., all especially fine and we feasted on these cocoa-nuts and pine-apples as we sailed along this picturesque, if somewhat barren, coast.

A short, flying trip was made to the Island of Kauai, the richest botanically of all the islands, as it is the oldest geologically. According to Hillebrand, not only is the number of species larger than in the other islands, buc the species are more specialised. Here I saw several species of the curious woody Lobeliaceæ, of which there are several genera that form either shrubs or small trees. I saw several species of Cyanea, with stems six to eight feet high, with long leaves crowded at the top of the stem and many white or purplish flowers, wuch like those of Lobelia, but somewhat larger and less open.

As in all the islands, there is on Kauai a great difference between the windward and leeward sides. I drove for abour thirty miles along the windward side of $\mathrm{this}$ island through some of the most beautiful scenery of all the islands. Near the sea were rolling plains and hills, with here and there groves of Pandanus and Hau-the latter a dense spreading small tree with large yellow hibiscus-flowers-and at one point we arove through a magnificent grove of kukui trees, the finest I saw anywhere. As we reached that part of the island which is most fully exposed to the moisture-laden trade-winds, vegetation became extremely luxuriant. Numerous valleys with clear streams flowing down them, their bottoms given up to rice plantations, were to be seen here, with the rice in all stages, from the young spears just standing above the water to golden-yellow patches of ripe grain. At Hanalei, my destination, I found excellent accommodation and a delightful bathing beach, the latter especially attractive after a thrrty-five mile urive over dusty roads. Hanalei is beautifully situated on a picturesque bay, with bold mountains rising directly back. The next morning a native was hired to go with me into the woods, and the day was spent in collecting.
The variety of trees, as well as other phænogams, is much greater here than in Hawaii ; the ferns, also, were very fine. Here I obtained a prize in a fine lot of the prothallia and young plants of Marattia, as well as some other interesting things.

Want of space forbids going into details, but no botanist visiting the islands can afford to miss Kauai.

In position, the Hawaiian Islands are unique, being more isolated than any other land of equal area upon the globe. More than 2000 miles separates them from the mainland, and $\mathbf{1} 860$ miles from the nearest high islands. Of purely volcanic origin, thrown up from an immense depth, they have always been thus isolated. As might be expected, the flora is very peculiar, more so than in any other country. According to Hillebrand, of 800 species of spermaphytes and pteridophytes that are strictly indigenous, 653 , or 75 per cent., are endemic. Taking out the pteridophytes, the spermaphytes show over 8I per cent.; and the dicotyledons over 85 per cent. that are found only in this group.

For a thorough study of this very curious flora, a long time would be necessary, as many species are extraordinarily local, and many of the most interesting localities are very difficult of access. The islands differ extremely among themselves, and exhibit in a most interesting manner the correspondence that exists between the variety and differentiation of forms and the ages of the islands. The formation of the islands has proceeded from north to south; and Kauai, the northernmost of the large islands of the group, is also the oldest and much the richest botanically, especially as regards spermaphytes ; and, according to Hillebrand, the genera and species are more differentiated. Hawaii, the southernmost of the islands, is much the poorest in forms, although in the Hilo district the conditions are most favourable for a luxuriant development of forms.

In the latter island is the last active volcano of the group, Mauna Loa, with its two craters, of which the well-known crater of Kilauea is the great sight of the islands, and visited constantly by tourists from all parts of the world.

A. few days after my return to Honolulu from Kauai, and six weeks from my first arrival there, I boarded the Monowai, the through Australian steamer bound for San Francisco, which was reached in due season after an uneventful passage. And so ended my first trip to the tropics.

\section{INSTRUMENTS FOR THE EARTHQUAKE}

\section{LABORATORYAT THE CHICAGO EXPOSITION.}

THE first earthquake instrument ever invented, a drawing of which is shown on the wall, is in all probability that of Chōkô, dating from the year A.D. I32. The first instrument used for keeping systematic records in Japan was Palmieri's modification of the contrivance sketched vut by the late Robert Mallet. Since this not only have all forms of seismographs and seismoscopes employed in Europe and America been employed, but many special forms have been designed in Japan, with the result that rather than Japan borrowing from Europe and America, these countries are using inventions which had their origin in Japan. A few of these instruments are exhibited in this laboratory. The main feature in their construction is that they all work from "steady points," and for small earthquakes at least, we can say with confidence that the diagrams they yield are absolute measurements of the earth's motion. From diagrams written on stationary plates we know the extent and the direction of the principal vibrations in a shock, but when the movements are recorded on a moving surface, we know the period or the rapidity with which the movements follow each other. From these latter diagrams the acceleration or suddenness of movements may be calculated, and the factors given to engineers enabling them to construct to resist known forces, rather than simply building strongly because an earthquake is strong.

\section{INSTRUMENTS EXHIBITED.}

I. Seismograph zuriting on a glass disc.-Here we have horizontal pendulums writing the earth's motion as two rectangular components on the surface of a smoked glass plate. The vertical motion is given by a vertical spring lever seismograph. The rate at which the plate revolves is accurately marked by an electrical time ticker. The movements of the latter are governed by a pendulum swinging across and making contacts with a small vessel of mercury.

No. [ 2 I5, VOL. 47$]$ 